\title{
A CONCEPT OF RELIABILITY ASSESSMENT SIMULATION MODEL USING SYSTEMS STRUCTURAL DECOMPOSITION
}

\section{KONCEPCJA MODELU SYMULACYJNEGO \\ DO SZACOWANIA NIEZAWODNOŚCI Z ZASTOSOWANIEM DEKOMPOZYCJI STRUKTURALNEJ UKLADÓW}

\author{
Stanisław Młynarski ${ }^{1}$, Robert Pilch ${ }^{2}$, Maksymilian Smolnik ${ }^{2}$, \\ Jan Szybka², Grzegorz Wiązania ${ }^{2}$ \\ ${ }^{1}$ Cracow University of Technology, Politechnika Krakowska \\ ${ }^{2}$ AGH University of Science and Technology, Akademia Górniczo-Hutnicza
}

\begin{abstract}
The paper presents a concept of reliability estimation of the renewable technical systems consisting of the objects functioning in koon structures. The estimation is performed using computer simulation. Practical dependence between the failure of the entire system and the failures of the objects and elements from which the objects are made are taken into account as the result of the structural decomposition of the system conducted.
\end{abstract}

Keywords: reliability, reliability structures, computer simulation, decomposition

Streszczenie: $W$ artykule przedstawiono koncepcje szacowania niezawodności odnawialnych uktadów technicznych sktadajacych się z obiektów funkcjonujacych $w$ strukturach typu $k z$, przy wykorzystaniu symulacji komputerowej. Wystęujace w praktyce zależności między uszkodzeniem układu a uszkodzeniami obiektów go tworzacych $i$ elementów, $z$ których sktadaja się obiekty, uwzględniono poprzez wykonana dekompozycje strukturalnq układu.

Slowa kluczowe: niezawodność, struktury niezawodnościowe, symulacja komputerowa, dekompozycja 
A concept of reliability assessment simulation model using systems structural...

Koncepcja modelu symulacyjnego do szacowania niezawodności z zastosowaniem. .

\section{A CONCEPT OF RELIABILITY ASSESSMENT SIMULATION MODEL USING SYSTEMS STRUCTURAL DECOMPOSITION}

\section{Introduction}

Complex technical systems are composed of objects which in turn are built up of subsystems and elements. The number of elements, which are essential for the reliability of the entire system, may be significant. The impact of each of these elements on the system's reliability is difficult to evaluate but may be important for planning and selection of reservation method that ensures the operational reliability expected level.

In the present paper a concept of a reliability assessment model using systems structural decomposition is proposed which enables the evaluation of the reliability of a set of interacting objects of correct performance probability distribution, whose actual values of parameters will result from in-service tests.

The calculation example is limited to a system composed of three objects working in a 2 out of 3 structure, each composed of four elements whose reliability affects the correct operation of the entire technical system. The model has a universal character and is applicable for koon structures and various probability distributions describing the reliability of elements.

\section{Characteristics of some simulation methods}

Simulation means imitation of the behaviour of systems, objects or processes which for various reasons are difficult to evaluate in in-service tests. Such tests are costly and that is why simulation methods are useful since they enable multiple repetition of the experiment at low cost. Simulation requires that a model be built that imitates the functioning of a real-world system, on which model experiments are performed to study the system's characteristics and changes in time $[3,7,13]$. One of the numerous simulation models is the mathematical model based simulation, i.e. numerical simulation. The basic tool used in numerical simulation is a computer program which is a formal representation of the adopted model of a system in question. The important advantages of computer simulation include the reduction of time and cost of tests and, unlike laboratory tests, the possibility of multiple repetition of experiment in identical conditions. Making use of computer simulation as a test method, however, it should always be remembered that the adopted mathematical model, as a simplified image of a selected section of the real world, does not account all important interrelationships occurring in a real-world system. This may sometimes make the simulation results an insufficient approximation of the investigated phenomenon.

Basically, computer simulation models are divided into continuous simulation and discrete simulation $[8,9]$. 
However, if in both cases the manner of changes of state in the modelled system and the manner of simulated time mapping are taken into account, it is possible to distinguish four main types of simulation, in which the change of system state proceeds [9]:

- in a manner continuous at any instant, i.e. variables change steplessly and their values are available for each value of time passed in simulation,

- in a manner continuous at discrete moments, i.e. variables change steplessly but their values are available only for certain values of time passed in simulation,

- stepwise at any instant, i.e. the values of variables are discrete but changes can occur at any instant,

- stepwise at discrete instants, i.e. state changes can occur only at certain instants.

The case study in the present paper refers to point $\mathrm{d}$ above. This simulation can be treated as discrete, i.e. one in which in the description of both changes in the system state and the time passed discrete functions are used. Changes in the system state occur stepwise at definite instants between which the system state does not change. In this simulation, on the basis of time step their two types can be distinguished. In one of these the simulated time is divided into intervals of a constant length and the simulation proceeds in steps equal to the interval length. The values of system state variables are determined at the end of each step, and all the events in a given step are treated as simultaneous and independent. In the other type the simulation step length is determined by the instants at which the system state variables change their values. These changes are called events and the sequence of these events determines simulation subsequent steps of different length. Simulation of this type is illustrated by simulation based on events planning.

Simulations can be classified following numerous types of criteria, but regardless which type of simulation is used, they are a very useful way of running tests particularly when other methods fail. To achieve the test target using numerical simulation the following activities are performed $[4,5,11]$ :

- formulation of problem and aim of simulation,

- development of a mathematical model of the investigated object,

- development of computer program,

- verification of model validity,

- planning simulation experiments,

- performance of simulation runs,

- analysis of results.

Following the procedure presented above a stochastic simulation model of a constant simulation step was developed. The model was applied for the evaluation of the reliability of reparable systems of koon hierarchical structures. 
A concept of reliability assessment simulation model using systems structural...

Koncepcja modelu symulacyjnego do szacowania niezawodności z zastosowaniem. .

\section{Structural decomposition of technical systems}

Units within technical objects subjected to decomposition can be ordered by the introduction of relevant factors and indices in order to identify particular elements. Each element should be identified in a separate way. Since there is a large number of elements of the same kind (i.e. distinguished at the same decomposition level, cf. [10]), it is necessary to differentiate them by assigning them different indices. Such an approach enables unambiguous identification of particular elements during tests, analyses as well as maintenance or modernisation operation. Thereby it is of great practical significance especially in the aspect of operation data storage, formulation of operation guidelines or diagnostics projects (cf. [12]). The proposed solution was illustrated by the model presented in the paper.

In the study case, a group of objects, here called a system, is subjected to two-level decomposition. The technical system $U_{i}$ is composed of a certain number $m_{P, i}$ of complex technical objects $P_{i, j}$ (defined as subsystems), which can be written as:

$$
U_{i}=\left\{P_{i, 1}, P_{i, 2}, \ldots, P_{i, j}, \ldots, P_{i, m_{P, i}}\right\},
$$

where: $i$-indicates the analysed technical system.

Moreover:

$$
j=1,2, \ldots, m_{P, i},
$$

where: $m_{P, i}$ - number of complex technical objects (subsystems) in the analyses done for system $U_{i}$.

Moreover, in general the following may hold:

$$
i=1,2, \ldots, m_{U},
$$

where: $m_{U}-$ number of technical objects in analyses.

At the same time, within the complex technical objects (subsystems) simple objects, called elements $E_{i, j, k}$ are distinguished. Therefore:

$$
P_{i, j}=\left\{E_{i, j, 1}, E_{i, j, 2}, \ldots, E_{i, j, k}, \ldots, E_{i, j, m_{E, i, j}}\right\},
$$

where: $j$-indicates the analysed complex technical object (subsystem) within the system;

moreover:

$$
k=1,2, \ldots, m_{E, i, j},
$$

where: $m_{E, i, j}$ - number of elements of subsystem $P_{i, j}$.

Understandably, between the numbers of particular units there is a dependence:

$$
\wedge_{U_{i}} m_{P, i}<\sum_{j=1}^{j=m_{P, i}} m_{E, i, j}
$$

because each of the units of the higher order contains a number of units of lower order. 
Stanisław Młynarski, Robert Pilch, Maksymilian Smolnik, Jan Szybka, Grzegorz Wiazania

The real-life transportation systems can be subjected to decomposition following the presented procedure. Then the transportation system is treated as a system within which technical objects (subsystems) are distinguished. The reliability structure of a technical object depends on its functional structure and is a natural consequence of the role of element in the process of task execution. Reliability structures play an essential role in the analyses of technical systems. The theory or reliability offers many possibilities for the analysis of various aspects of reliability of real-world technical objects provided data or at least premises on reliability models and structures are available [1]. Obviously, states of reliability of particular elements affect the reliability state of the entire system, and mapping of the states of elements onto the state of the system is called its reliability structure. Therefore, the system's reliability structure depends on:

- distinguishing elements within the system,

- functional interrelationships between elements, i.e. on system's functional structure,

- adopted criterion of failure of elements and the entire system,

- task performed by the system.

To determine the reliability structure it is necessary to perform a thorough analysis of the system. This requires the knowledge of its structure, as well as the design and functioning of its elements and the tasks performed by the system together with their evaluation criteria. What is very important is also experience in modelling and analysis of the reliability of real-life technical objects.

In real-life conditions of transportation systems operation there may be found reliability structures controlled by internal conditions and external factors that appear during their operation. The required functional and economic effectiveness of transportation systems depends on their reliability. The efficiency of transportation means management is, consequently, a reliability function of vehicles' use process. A system's reliability function to a large extent results from the reliability structure. It can therefore be maintained that the system of management, the system of use, the system of financing and the systems of vehicles destruction impact on the actual system of vehicles operation by corresponding reliability structures.

It can be concluded that what plays the dominant role in the process of effective use of fixed assets are the problems of shaping reliability structures, next expenditure and reliabilities of elements (vehicles) of these systems.

For this reason, it is of essential significance to apply computer simulation methods to assess reliability fast in order to maximise the effectiveness of a transportation business. Modern transportation systems are composed of a huge number of vehicles of identical design, therefore the impact of the reliability of individual design elements on the reliability of the entire system is potentially substantial. The correct configuration of a koon reliability structure of a transportation system and the simulation based verification of its reliability enable efficient operation of a transportation business. 
A concept of reliability assessment simulation model using systems structural...

Koncepcja modelu symulacyjnego do szacowania niezawodności z zastosowaniem. .

All the arguments above have resulted in the idea of developing the simulation model proposed in the present paper.

\section{A concept of structural decomposition based simulation model}

In view of the immediate need to assess the reliability of complex systems making use of data on the reliability of elements of objects (subsystems) operating in these systems a calculation model of stochastic simulation of a constant time step is proposed. The model is applicable for koon structures (cf. [6]). The essential input information used in calculations is the data on the probability distributions of timeto-failure of particular elements of each subsystem. These data should be obtained from operational tests of real objects. The proposed solution enables the use of the majority of probability distributions that are applied in reliability engineering.

The model enables monitoring the effect of reliability of individual elements on the reliability of the entire system. This information is crucial for designers who form the reliability of technical objects. The proposed hierarchical structure of a system is shown in figures 1 and 2 .

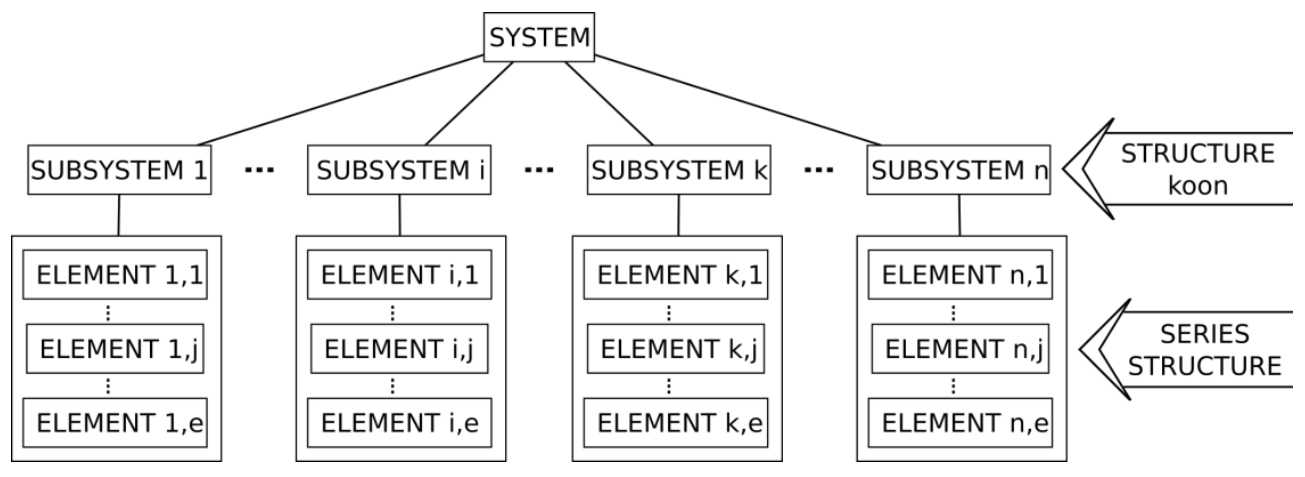

Fig. 1 Functional structure of a koon system with objects composed of series structures of elements

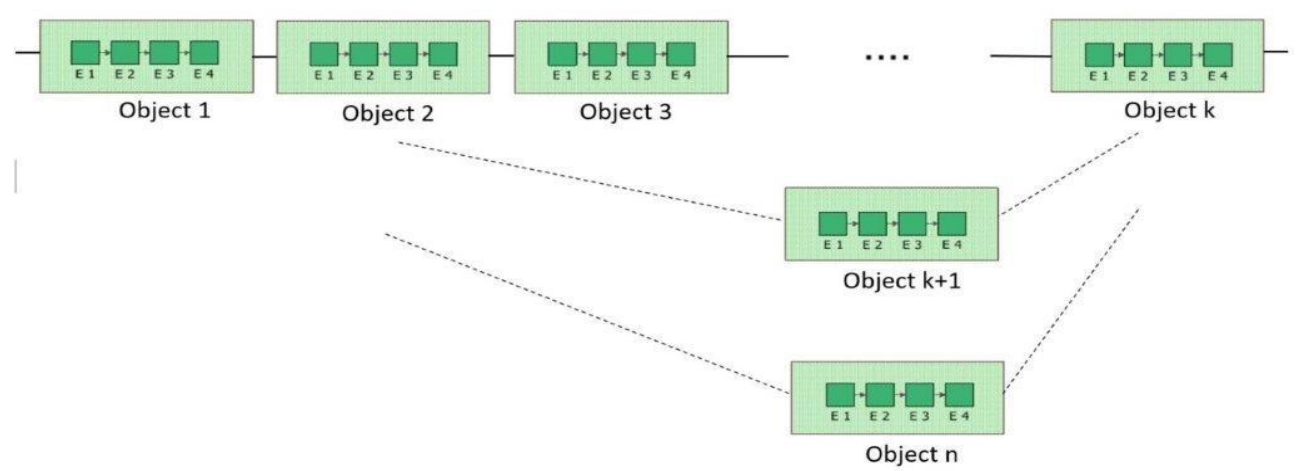

Fig. 2 Reliability structure of the system discussed 
In the structural model (figure 1) three layers can be distinguished: system, subsystems and elements (cf. [2]). The system is composed of subsystems functioning in a koon structure, while the subsystems are composed of elements functioning in an series structure.

The model of states and transitions for a system, subsystem and element are shown in figure 3.
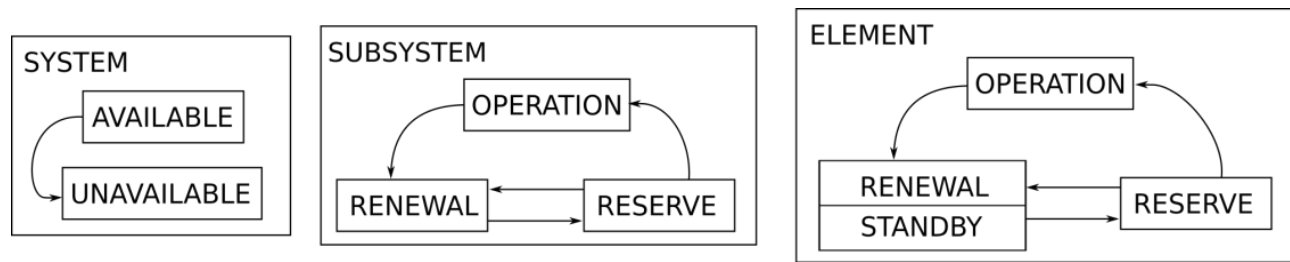

Fig. 3 Model of reliability and operation states and transitions for a system, subsystem and element

The reliability state of a system depends entirely on the state of subsystems, according to the rules valid for koon structures. The relationships between the subsystem and elements it is composed of are more complex. If a subsystem is in the state of availability, i.e. is functioning or is held in reserve, it imposes its operational state on its component elements provided none of the elements is held in renewal. In case of a failure of an element and its transition from the availability state to the unavailability state, it imposes its state on the subsystem it is component of (the given subsystem passes to the renewal state). Only failed elements are held in the renewal state while unfailed elements that belong to the subsystem in renewal are on standby awaiting to be included in the reserve, and it is assumed that they cannot fail and their age does not change.

The simulation method involves performing a specific number of iterations. Each of these is a mapping of the work of the system modelled. Iteration runs in a discrete period of time and is divided into steps. The interval between steps is denoted $\Delta t$. In each iteration step for each working element the condition for reliability state described by equation:

$$
\text { rnd } \leq P_{Z} \text {, }
$$

where:

$r n d$ - random number from $[0,1]$ interval of uniform distribution,

$P_{Z}$ - probability of element state change in $(t, t+\Delta t)$ interval provided the element did not fail until time $t$ is checked.

If this condition is met, the element's operational state is changed from operation into repair. The change of state from renewal to reserve always takes place after a specific repair time. The transition from reserve to renewal is determined in a similar way as the transition from work to renewal, the difference being that for element held in reserve time passes $p$ times slower, where $p$ is the input parameter for simulation. 
A concept of reliability assessment simulation model using systems structural...

Koncepcja modelu symulacyjnego do szacowania niezawodności z zastosowaniem. .

The presented calculation algorithm was applied in the simulation of a system of 2 out of 3 structure with elements whose time to failure was described by Weibull distribution following the formula below and of parameters given in table 1 together with the other parameters used in the simulation.

$$
f(t)=\frac{c}{s}\left(\frac{t}{s}\right)^{c-1} \exp \left(-\left(\frac{t}{s}\right)^{c}\right),
$$

where:

$c$ - parameter of shape,

$s$ - parameter of scale.

Tab. 1 Weibull distribution parameters describing reliability of particular elements and times of repair

\begin{tabular}{|c|c|c|c|c|}
\hline Element & $c$ & $s$ [days] & $t_{\text {odn }}$ [days] & $p$ \\
\hline 1 & 1,39 & 282,17 & 5 & 5 \\
\hline 2 & 1,39 & 1975,91 & 2 & 5 \\
\hline 3 & 1,39 & 1410,81 & 1 & 5 \\
\hline 4 & 1,39 & 846,49 & 4 & 5 \\
\hline
\end{tabular}

The reliability of a system of 2 out of 3 structure obtained using the simulation method developed is shown in figure 4.

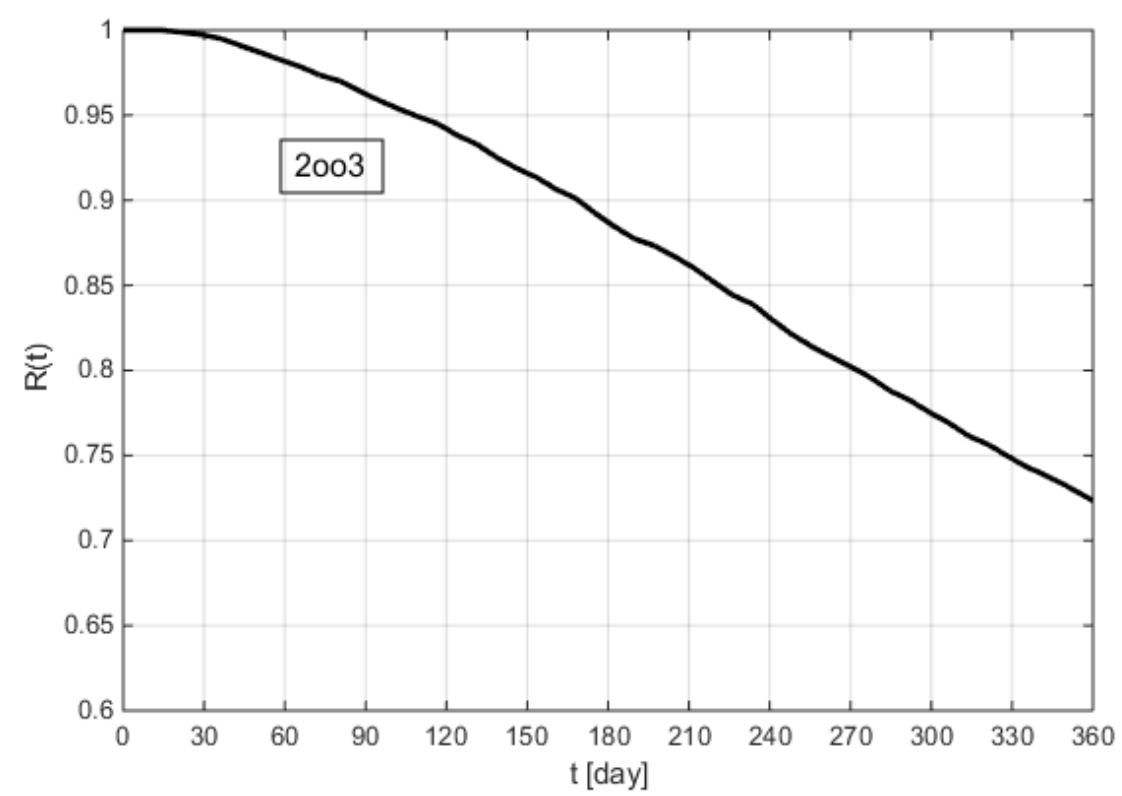

Fig. 4 Model of reliability and operation states and transitions for a system, subsystem and element 
The results of system reliability assessment obtained using the simulation model developed indicate that the reliability of the system in question after one year of its operation reaches the value of about 0,72 . This is primarily due to the repair times of individual elements, which depend on the access to servicing.

\section{Verification of simulation model}

To test the proposed reliability simulation algorithm decomposition of a transportation system was performed at two levels. Vehicles executing transport tasks identified as subsystems were specified. The other decomposition level covered vehicle fundamental units, i.e. the body, engine, power transmission and drive chain. The units are elements of subsystems separated out of the entire analysed system. The analysis indicates that due to the functional structure and design characteristics as well as operational tasks of objects (subsystems) the elements are arranged in a reliability series structure. The series structure affects unfavourably the object's (subsystem's) behaviour in operation and contributes to considerable decrease of reliability due to poorer reliability of one of the elements. With the aim of mapping the real-life reliability structure of objects a 2 out of 3 vehicles structure was proposed.

Verification of calculation validity of the proposed simulation model was carried out by the comparison of the simulation results with those obtained for the same case using Markov processes. A system of 2 out of 3 structure was analysed in which objects (subsystems) are homogeneous and each is composed of four elements making up a series arrangement. Time to failure and time to repair of each element is described by exponential distribution of parameters given in table 2. An important assumption adopted in the model is that following a failure of any element the entire subsystem changes to the state of renewal in which the failed element is repaired, and until the renewal is complete the other elements of this subsystem do not fail.

Tab. 2 Failure and repair rates of component elements of a subsystem

\begin{tabular}{|c|c|c|c|}
\hline $\begin{array}{c}\text { No. } \\
\text { element }\end{array}$ & $\begin{array}{c}\text { Failure rate } \\
\lambda[1 / \text { day }]\end{array}$ & $\begin{array}{c}\text { Failure rate in } \\
\text { reserve } \lambda_{r}[1 / \text { day }]\end{array}$ & $\begin{array}{c}\text { Repair rate } \\
\mu[1 / \text { day }]\end{array}$ \\
\hline 1 & $13,7 \cdot 10^{-3}$ & $2,74 \cdot 10^{-3}$ & 0,333 \\
\hline 2 & $0,548 \cdot 10^{-3}$ & $0,11 \cdot 10^{-3}$ & 0,25 \\
\hline 3 & $2,74 \cdot 10^{-3}$ & $0,548 \cdot 10^{-3}$ & 0,5 \\
\hline 4 & $16,4 \cdot 10^{-3}$ & $3,29 \cdot 10^{-3}$ & 0,2 \\
\hline
\end{tabular}


A concept of reliability assessment simulation model using systems structural...

Koncepcja modelu symulacyjnego do szacowania niezawodności z zastosowaniem..

Markov process graph for the investigated case is shown in figure 5.

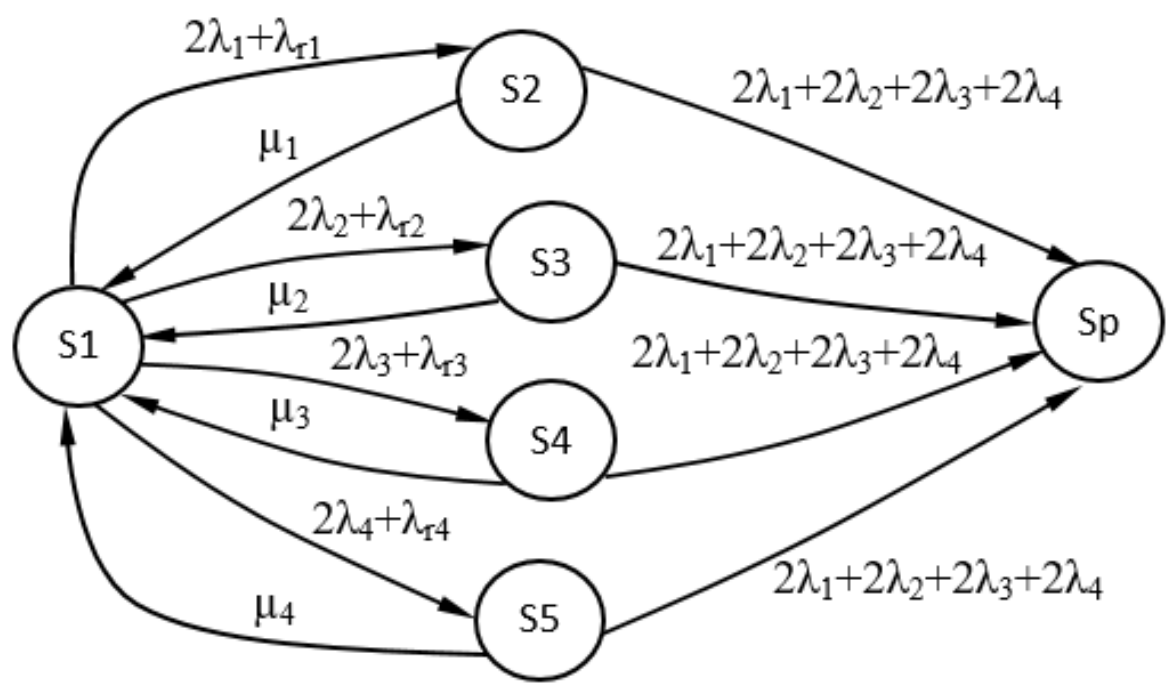

Fig. 5 Markov process graph for 2 out of 3 system after the proposed calculation model

The system of differential equations takes the form:

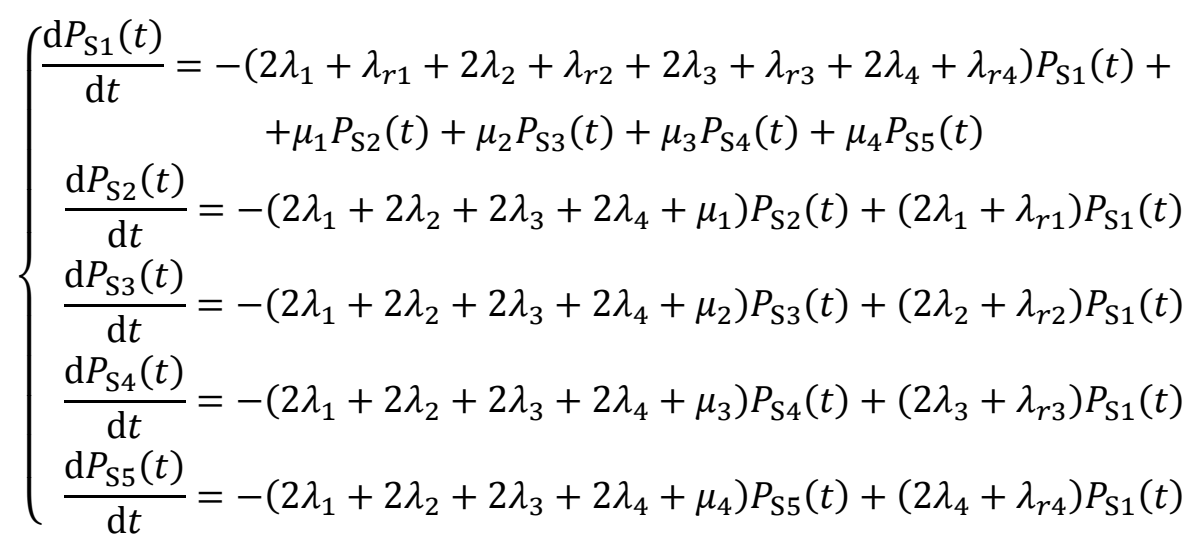

The results of calculations are changes in the system's reliability over the adopted computations time horizon, which is shown in figure 6.

From the results it clearly follows that the differences in reliability curves from the simulation model and analytic solution are but minor. It can be assumed that the simulation calculation model functions correctly and can be applied for the reliability assessment of systems of this type in the case of probability distributions of elements time to failure and time to repair other than exponential. 


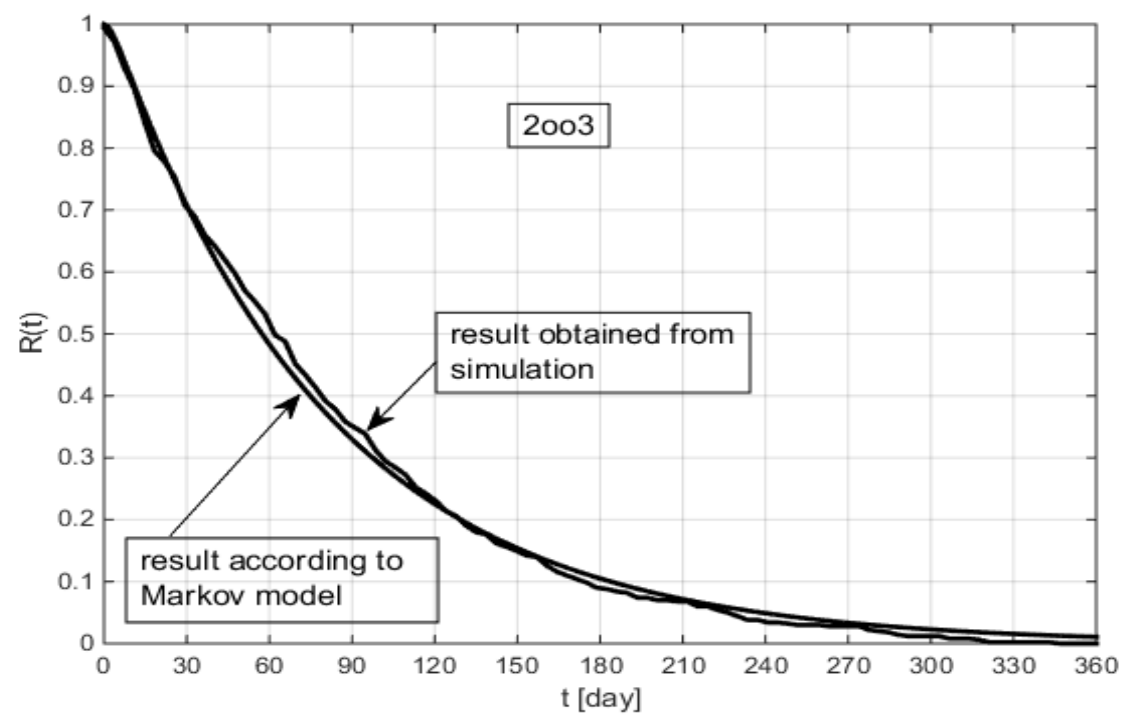

Fig. 6 Reliability of 2 out of 3 system obtained by simulation and with the application of Markov processes

\section{Conclusions}

The presented concept of a simulation model and the calculations performed are innovative.

The concept of the model is based on structural decomposition of a system into three levels: the system, subsystems and element. For real-life transportation systems this division can be referred to as a set of vehicles (of a transportation system), vehicles and their subassemblies, respectively, which determine the reliability of the entire system. The reliability of elements was defined by probability distributions of parameters adopted on the basis of operational tests. The subsystems were composed of elements and operated in koon structures. The performed simulations resulted in the reliability assessment of the entire system.

The simulation program was verified for the validity of its functioning. The results were favourable.

The model can be extended by another decomposition level in which the element will represent the machinery part - a component of the subassembly of the vehicle - a component of the transportation system.

\section{References}

[1] Bradley E.: Reliability Engineering: A Life Cycle Approach. CRC Pres Taylor \& Francis Group. 2017.

[2] Faulin Fajardo J., Juan Perez A.A., Martorell Alsina S.S., Ramirez-Marquez J.E. (ed.): Simulation Methods for Reliability and Availability of Complex Systems. Springer. 2010. DOI 10.1007/978-1-84882-213-9. 
A concept of reliability assessment simulation model using systems structural...

Koncepcja modelu symulacyjnego do szacowania niezawodności z zastosowaniem. .

[3] Fishman G.S.: Symulacja komputerowa. Pojęcia i metody. PWE. Warszawa. 1981.

[4] Jaźwiński J., Pabis S., Wieremiejczyk W.: Zasady symulacji systemów technicznych, [in]: Symulacyjne metody badań niezawodności systemów technicznych 1. Materiały na „Szkołę Zimową - 75”. Sekcja Podstaw Eksploatacji Maszyn PAN. Ośrodek Postępu Technicznego. Katowice. 1975.

[5] Łatuszyńska M.: Metody symulacji komputerowej - próba klasyfikacji logicznej. Studies \& Proceedings of Polish Association for Knowledge Management. 2011; 41: 163-176.

[6] Młynarski S., Pilch R., Smolnik M., Szybka J., Wiązania G.: Formation of koon Systems Reliability Estimated with Analytical and Simulation Calculation Methods. Zapewnienie wymaganej niezawodności układów typu „kzn” szacowanej analitycznymi i symulacyjnymi metodami obliczeniowymi. Journal of KONBiN. 2017; 42: 255-272.

[7] Naylor T.H.: Modelowanie cyfrowe systemów ekonomicznych. PWN. Warszawa. 1975.

[8] Perkowski P.: Technika symulacji cyfrowej. WNT. Warszawa. 1980.

[9] Pidd M.: Computer Simulation in Management Science. John Wiley \& Sons. Chichester - New York - Weinheim - Brisbane - Singapore - Toronto. 1998.

[10] Pilch R., Smolnik M., Szybka J., Wiązania G.: Koncepcja strategii odnów profilaktycznych na przykładzie pojazdów szynowych komunikacji miejskiej [in] Siergiejczyk M. [ed.]: Problemy utrzymania systemów technicznych. Oficyna Wydawnicza Politechniki Warszawskiej. Warszawa. 2014.

[11] Snopkowski R.: Symulacja stochastyczna. Uczelniane Wydawnictwa Naukowo-Dydaktyczne AGH. Kraków. 2007.

[12] Sowa A.: Ocena stanu technicznego pojazdów szynowych na podstawie cech zdeterminowanych. PK im. Tadeusza Kościuszki. Kraków. 2013.

[13] Tyszer J.: Symulacja cyfrowa. WNT. Warszawa. 1990.

\section{This work was financed by AGH University of Science and Technology, Faculty of Mechanical Engineering and Robotics, research program No. 11.11.130.174.}




\section{KONCEPCJA MODELU SYMULACYJNEGO DO SZACOWANIA NIEZAWODNOŚCI Z ZASTOSOWANIEM DEKOMPOZYCJI STRUKTURALNEJ UKLADÓW}

\section{Wprowadzenie}

Złożone układy techniczne składają się $\mathrm{z}$ obiektów, które zbudowane są z podzespołów i elementów. Liczba tych elementów, mających istotne znaczenie ze względu na niezawodność całego układu, może być znacząca. Wpływ każdego z nich na niezawodność całego układu jest trudny do oceny, ale może mieć istotne znaczenie w planowaniu i doborze sposobu rezerwowania, gwarantującego oczekiwany poziom niezawodności eksploatacyjnej.

W niniejszym opracowaniu przedstawiono koncepcję modelu symulacyjnego do szacowania niezawodności przy uwzględnieniu dekompozycji strukturalnej układów, który umożliwi ocenę niezawodności zbioru współpracujących obiektów o rozkładach prawdopodobieństwa poprawnej pracy, których rzeczywiste wartości parametrów będą wynikiem badań eksploatacyjnych.

Przykład obliczeniowy ograniczono do układu składającego się z trzech obiektów pracujących w strukturze progowej 2z3, posiadających po cztery elementy, których niezawodność ma wpływ na poprawną pracę całego układu technicznego. Opracowywany model będzie miał charakter ogólny i znajdzie zastosowanie dla struktur typu kzn i różnych rozkładów prawdopodobieństwa opisujących niezawodność elementów.

\section{Charakterystyka wybranych metod symulacyjnych}

Symulacja jest to sztuczne odtwarzanie zachowania się systemów, obiektów lub przebiegu procesów, które ze względu na różne aspekty są trudne w bezpośredniej ocenie w badaniach eksploatacyjnych. Koszty tych badań są wysokie i dlatego użyteczne są metody symulacji wymienionych procesów, gdyż umożliwiają wielokrotne powtarzanie eksperymentu przy niskich nakładach. Na potrzeby realizacji symulacji buduje się model imitujący funkcjonowanie rzeczywistego systemu, a następnie poprzez eksperymenty $\mathrm{z}$ modelem studiuje się charakterystykę i zmiany tego systemu w czasie $[3,7,13]$. Spośród wielu modeli symulacyjnych można wyróżnić symulację przeprowadzaną na podstawie modelu matematycznego i wtedy mówimy o symulacji numerycznej (cyfrowej). Podstawowym narzędziem wykorzystywanym w symulacji cyfrowej jest program komputerowy stanowiący formalną reprezentację przyjętego modelu badanego systemu. Do podstawowych zalet symulacji komputerowej należy zaliczyć skrócenie czasu i zmniejszenie kosztów badań oraz, w odróżnieniu od badań laboratoryjnych, możliwość wielokrotnego powtarzania eksperymentu w niezmienionych warunkach. 
A concept of reliability assessment simulation model using systems structural... Koncepcja modelu symulacyjnego do szacowania niezawodności z zastosowaniem. .

Wykorzystując symulację komputerową jako metodę badawczą, należy jednak zawsze brać pod uwagę, że przyjęty model matematyczny, jako uproszczony obraz wybranego fragmentu rzeczywistości, nie uwzględnia wszystkich istotnych zależności występujących w rzeczywistym systemie. Może to czasem powodować, że otrzymywane wyniki symulacji będą stanowiły niewystarczające przybliżenie badanego zjawiska.

Podstawowy podział komputerowych modeli symulacyjnych polega na wyróżnieniu symulacji typu ciągłego oraz symulacji typu dyskretnego $[8,9]$. Jeżeli jednak $\mathrm{w}$ obydwu wymienionych przypadkach zostanie uwzględniony sposób zmian stanu w modelowanym systemie oraz sposób odwzorowania symulowanego czasu, możliwe staje się wyróżnienie następujących czterech głównych typów symulacji, w których zmiana stanu systemu zachodzi [9]:

- w sposób ciągły w każdej chwili, czyli zmienne zmieniają się w sposób płynny i ich wartości są dostępne dla każdej wartości czasu upływającego w symulacji,

- w sposób ciągły w dyskretnych chwilach, czyli zmienne zmieniają się w sposób płynny, ale ich wartości są dostępne tylko dla określonych wartości czasu upływającego w symulacji,

- w sposób skokowy w każdej chwili, czyli wartości zmiennych są dyskretne, ale zmiany mogą nastąpić w każdej chwili,

- w sposób skokowy w dyskretnych chwilach, czyli zmiany mogą nastąpić tylko w określonych chwilach.

Rozpatrywany w artykule przypadek dotyczy ww. punktu d. Tę symulację można potraktować jako dyskretną czyli taką, w której zarówno w opisie zmiennych stanu systemu jak i upływu czasu wykorzystuje się funkcje dyskretne. Zmiany stanu systemu następują skokowo $\mathrm{w}$ określonych chwilach, a pomiędzy nimi stan systemu nie ulega zmianom. W obrębie tego rodzaju symulacji, ze względu na krok czasowy, można wyróżnić ich dwa podstawowe typy. Pierwszy z nich to taki, w którym czas symulowany podzielony jest na stałej długości przedziały i symulacja przesuwa się po jednym kroku równym długości przedziału. Wartości zmiennych stanu systemu określane są na koniec każdego kroku, a wszystkie zdarzenia $\mathrm{w}$ danym kroku traktowane są jako jednoczesne i niezależne. W drugim typie długość kroku symulacji wyznaczana jest przez chwile, w których zmienne stanu systemu zmieniają swoje wartości. Zmiany te nazywane są zdarzeniami, a sekwencja tych zdarzeń wyznacza kolejne kroki symulacji o różnej długości. Przykładem symulacji tego typu jest symulacja oparta na planowaniu zdarzeń.

Rodzajów kryteriów klasyfikacji symulacji jest wiele, ale bez względu na to jaki rodzaj symulacji jest wykorzystywany, stanowią one bardzo użyteczną formę prowadzenia badań szczególnie, gdy zawodzą inne metody. 
Do osiągnięcia celu badawczego $\mathrm{z}$ wykorzystaniem symulacji cyfrowej przeprowadza się następujące czynności $[4,5,11]$ :

- sformułowanie problemu i celu symulacji,

- wyznaczenie modelu matematycznego badanego obiektu,

- opracowanie programu komputerowego,

- weryfikacja poprawności modelu,

- zaplanowanie eksperymentów symulacyjnych,

- wykonanie przebiegów symulacyjnych,

- analiza wyników.

$\mathrm{W}$ artykule, zgodnie $\mathrm{z}$ wymienionym zakresem postępowania, opracowano stochastyczny model symulacyjny o stałym kroku symulacji, który został zastosowany do oceny niezawodności odnawialnych układów o hierarchicznych strukturach typu kzn.

\section{Dekompozycja strukturalna ukladów technicznych}

Porządkowanie jednostek wyróżnianych w obrębie obiektów technicznych poddawanych dekompozycji może zostać przeprowadzone na drodze wprowadzania odpowiednich wskaźników i indeksów celem oznaczenia poszczególnych elementów. Każdy element powinny w tym przypadku być oznaczany w odrębny sposób. Z uwagi na dużą liczbę elementów tego samego rodzaju (tj. wyróżnionych na tym samym poziomie dekompozycji, por. [10]), konieczne jest ich rozróżnianie poprzez przypisanie im zróżnicowanych indeksów. Opisane podejście umożliwia jednoznaczne identyfikowanie poszczególnych elementów podczas badań, analiz oraz działań o charakterze obsługowym i modernizacyjnym. Tym samym ma ono istotne znaczenie praktyczne, zwłaszcza w zakresie archiwizacji danych o eksploatacji, formułowaniu wytycznych eksploatacyjnych, czy realizacji działań diagnostycznych (por. [12]). Proponowane rozwiązanie zostało przedstawione na przykładzie odnoszącym się do modelu prezentowanego $\mathrm{w}$ artykule.

$\mathrm{W}$ rozpatrywanym przypadku, dwupoziomowej dekompozycji poddawana jest grupa obiektów - nazywana w tym miejscu układem. Analizowany układ techniczny $U_{i}$ składa się z określonej liczby $m_{P, i}$ złożonych obiektów technicznych $P_{i, j}$ (określanych jako podukłady), co można zapisać:

gdzie:

$$
U_{i}=\left\{P_{i, 1}, P_{i, 2}, \ldots, P_{i, j}, \ldots, P_{i, m_{P, i}}\right\},
$$

$i$ - wskazuje analizowany układ techniczny.

Poza tym:

gdzie:

$$
j=1,2, \ldots, m_{P, i},
$$

$m_{P, i}$ - liczba złożonych obiektów technicznych (podukładów) w rozważaniach prowadzonych dla układu $U_{i}$. 
A concept of reliability assessment simulation model using systems structural...

Koncepcja modelu symulacyjnego do szacowania niezawodności z zastosowaniem. .

Ponadto, ogólnie może być:

gdzie:

$$
i=1,2, \ldots, m_{U}
$$

$m_{U}-$ liczba układów technicznych w rozważaniach.

Jednocześnie, w obrębie wymienionych złożonych obiektów technicznych (podukładów) wyróżnia się obiekty proste, nazywane elementami $E_{i, j, k}$. Można zatem zapisać:

gdzie:

$$
P_{i, j}=\left\{E_{i, j, 1}, E_{i, j, 2}, \ldots, E_{i, j, k}, \ldots, E_{i, j, m_{E, i, j}}\right\},
$$

$j$ - wskazuje analizowany złożony obiekt techniczny (podukład) w obrębie układu; ponadto:

gdzie:

$$
k=1,2, \ldots, m_{E, i, j},
$$

$m_{E, i, j}$ - liczba elementów rozpatrywanego podukładu $P_{i, j}$.

Co zrozumiałe, pomiędzy liczbami poszczególnych wyróżnionych jednostek zachodzi zależność:

$$
\bigwedge_{U_{i}} m_{P, i}<\sum_{j=1}^{j=m_{P, i}} m_{E, i, j},
$$

gdyż każda z jednostek wyższego rzędu zawiera pewną liczbę jednostek niższego rzędu.

Rzeczywiste systemy transportowe mogą podlegać dekompozycji według przedstawionej metody. Wówczas wymieniony system traktowany jest jako układ, w obrębie którego wyróżnia się obiekty techniczne (podukłady). Struktura niezawodnościowa obiektu technicznego uzależniona jest od jego struktury funkcjonalnej i występuje jako naturalne następstwo roli elementu w procesie wykonywania postawionego przed nim zadania. Struktury niezawodnościowe odgrywają kluczową rolę $\mathrm{w}$ analizach układów technicznych. Teoria niezawodności daje wiele możliwości w zakresie analizy zagadnień niezawodności dotyczących rzeczywistych obiektów technicznych pod warunkiem, że dysponujemy danymi lub co najmniej przesłankami dotyczącymi modeli i struktur niezawodnościowych [1]. Oczywiście, stany niezawodnościowe poszczególnych elementów wpływają na stan niezawodnościowy układu, a odwzorowanie stanów elementów na stan układu nazywa się jego strukturą niezawodnościową. Wobec tego, struktura niezawodnościowa układu zależy od:

- wyróżnienia elementów w obrębie układu;

- funkcjonalnych powiązań między elementami, tzn. od struktury funkcjonalnej układu;

- przyjętego kryterium uszkodzenia elementów i całego układu;

- zadania wykonywanego przez układ.

Dla potrzeb określenia struktury niezawodnościowej należy dokonać szczegółowej analizy układu. 
Stanisław Młynarski, Robert Pilch, Maksymilian Smolnik, Jan Szybka, Grzegorz Wiazania

Wymaga to wiedzy o jego budowie, a także o budowie i funkcjonowaniu jego elementów oraz o zadaniach wykonywanych przez układ i kryteriach ich oceny. Bardzo istotne jest również doświadczenie $w$ modelowaniu i analizie niezawodności rzeczywistych obiektów technicznych.

W rzeczywistych warunkach eksploatacji systemów transportowych, mogą występować struktury niezawodnościowe zdeterminowane warunkami wewnętrznymi i czynnikami zewnętrznymi występującymi w trakcie ich eksploatacji. Zapewnienie wymaganej efektywności funkcjonalnej i ekonomicznej systemów transportowych zależy od ich niezawodności. Skuteczność procesu gospodarowania środkami transportu jest więc funkcją niezawodności procesu użytkowania pojazdów. Funkcja niezawodności systemu w dużej części wynika ze struktury niezawodnościowej. Można więc zauważyć, że system gospodarowania, system użytkowania, system finansowania oraz systemy destrukcji pojazdów oddziałują na rzeczywisty system eksploatacji pojazdów przez odpowiadające im struktury niezawodnościowe.

Wynika $\mathrm{z}$ tego, że nadrzędną rolę w procesie efektywnego użytkowania majątku trwałego zajmują zagadnienia dotyczące kształtowania struktur niezawodnościowych, a następnie koszty i niezawodności elementów (pojazdów) tych systemów.

$\mathrm{Z}$ tego względu istotne znaczenie ma zastosowania metod symulacji komputerowej do szybkiej oceny niezawodności w celu maksymalizacji efektywności przedsięwzięcia transportowego. Współczesne systemy transportowe składają się z bardzo dużej liczby pojazdów o identycznej konstrukcji, w związku z czym występuje w rzeczywistości potencjalnie duży wpływ niezawodności pojedynczych elementów konstrukcji na niezawodność całego systemu. Właściwa konfiguracja struktury niezawodnościowej typu kzn systemu transportowego i symulacyjna weryfikacja jej niezawodności umożliwiają efektywne funkcjonowanie przedsiębiorstwa transportowego.

Stąd też pojawił się problem opracowania prezentowanego w niniejszej pracy modelu symulacyjnego.

\section{Wpływ poziomu rezerwowania na czas pracy układu kzn do osiągnięcia granicznego dopuszczalnego poziomu niezawodności}

Wobec istniejącej potrzeby szacowania niezawodności złożonych układów z wykorzystaniem informacji o niezawodności elementów obiektów (podukładów) pracujących $\mathrm{w}$ tych układach, zaproponowano obliczeniowy model symulacji stochastycznej o stałym kroku czasowym, który ma mieć zastosowanie dla struktur progowych typu kzn (por. [6]). Podstawową informacją wejściową wykorzystywaną w obliczeniach są dane o rozkładach prawdopodobieństwa czasu pracy do uszkodzenia pojedynczych elementów każdego z podukładów. Dane te powinny być uzyskiwane w wyniku badań eksploatacyjnych rzeczywistych obiektów. 
A concept of reliability assessment simulation model using systems structural...

Koncepcja modelu symulacyjnego do szacowania niezawodności z zastosowaniem. .

Opracowane rozwiązanie umożliwia wykorzystywanie większości spośród rozkładów prawdopodobieństwa znajdujących zastosowanie w inżynierii niezawodności.

Opracowany model umożliwia obserwację wpływu niezawodności poszczególnych elementów na niezawodność całego układu. Informacja ta jest istotną wskazówką dla projektantów kształtujących niezawodność obiektów technicznych. Rozpatrywana hierarchiczna struktura układu przedstawiona została na rysunkach 1 i 2 .

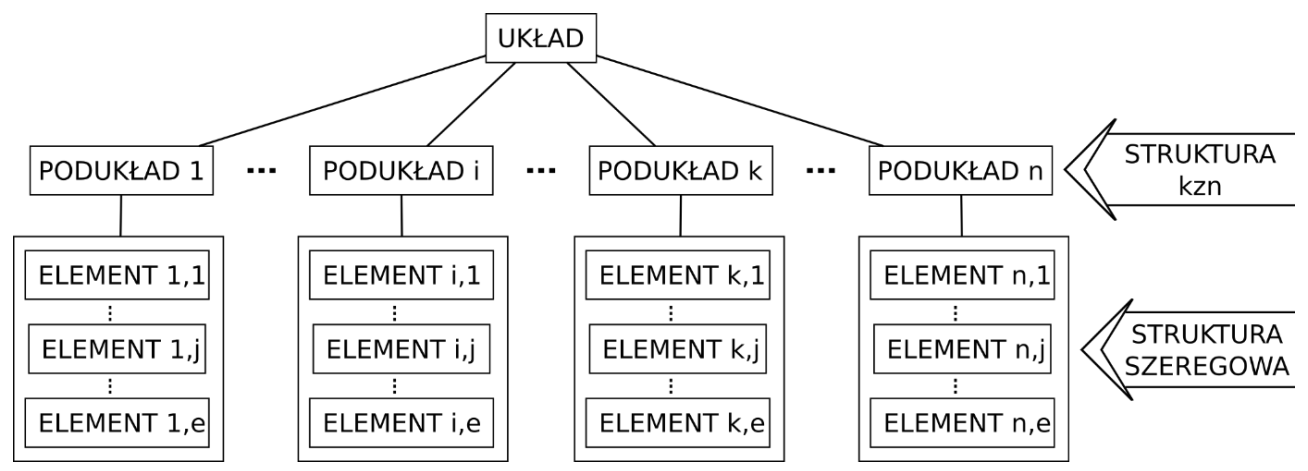

Rys. 1 Struktura funkcjonalna układu kzn z obiektami sktadajacymi się z szeregowych połączeń elementów

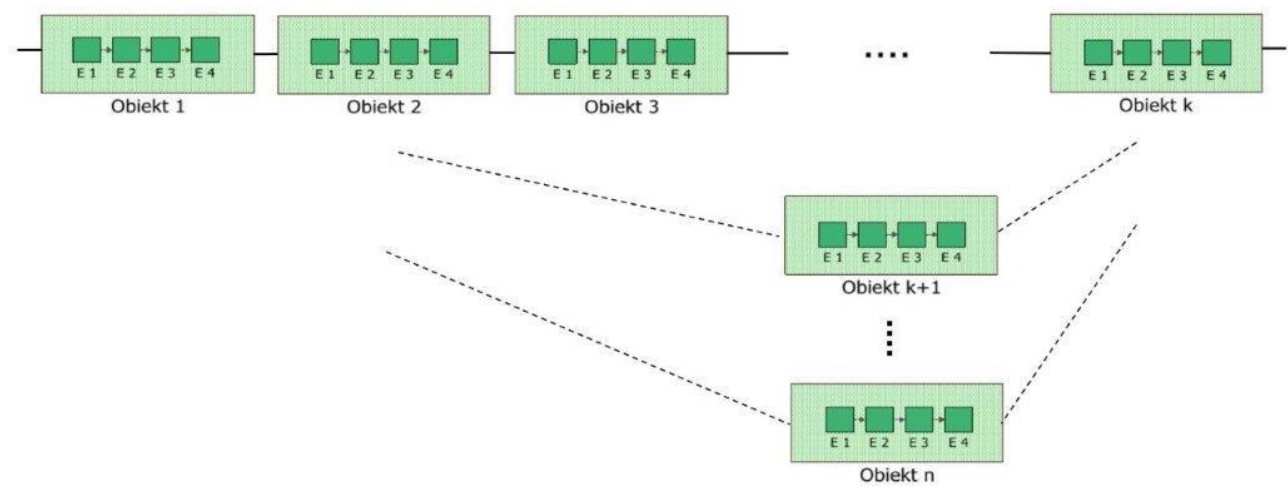

Rys. 2 Struktura niezawodnościowa rozpatrywanego układu

W modelu strukturalnym (rysunek 1) można wyróżnić trzy warstwy: układu, podukładów i elementów (por. [2]). Układ złożony jest $\mathrm{z}$ podukładów funkcjonujących $\mathrm{w}$ strukturze kzn, a podukłady $\mathrm{z}$ elementów funkcjonujących w strukturze szeregowej.

Model stanów i przejść dla układu, podukładu i elementu pokazano na rysunku 3. 
Stanisław Młynarski, Robert Pilch, Maksymilian Smolnik, Jan Szybka, Grzegorz Wiazania
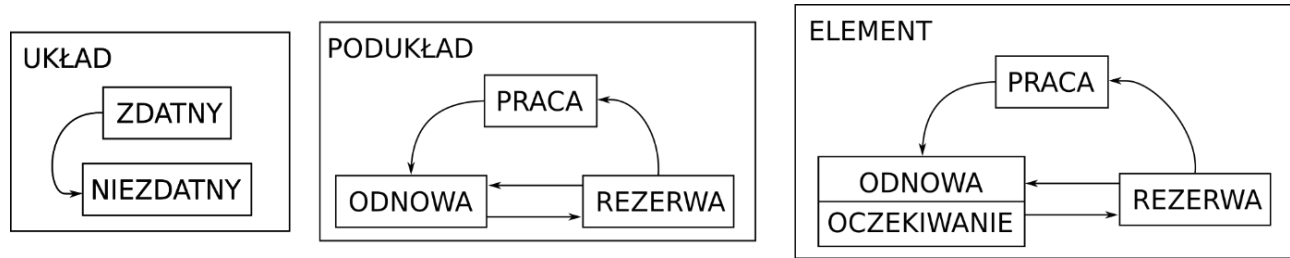

Rys. 3 Model stanów niezawodnościowych i eksploatacyjnych oraz przejść dla uktadu, poduktadu i elementu

Stan niezawodnościowy układu zależy wyłącznie od stanu podukładów, zgodnie z regułami obowiązującymi dla struktur typu kzn. Relacje pomiędzy podukładem i elementami wchodzącymi w jego skład są bardziej złożone. Jeżeli podukład jest w stanie zdatności, tzn. pracuje lub jest w rezerwie, to narzuca on swój stan eksploatacyjny elementom wchodzącym w jego skład pod warunkiem, że żaden $\mathrm{z}$ elementów nie jest $\mathrm{w}$ odnowie. W przypadku uszkodzenia się elementu $\mathrm{i}$ jego przejścia ze stanu zdatności do stanu niezdatności, element ten narzuca swój stan podukładowi, do którego należy(wymieniony podukład przechodzi w stan odnowy). Tylko elementy uszkodzone znajdują się w stanie odnowy, natomiast elementy nieuszkodzone, znajdujące się w odnawianym podukładzie, są w stanie oczekiwania na włączenie do rezerwy i zakłada się, że nie mogą się one uszkodzić, a ich wiek nie ulega zmianie.

Metoda symulacyjna polega na wykonaniu określonej liczby iteracji. Każda z nich to odwzorowanie pracy modelowanego układu. Iteracja przebiega $\mathrm{w}$ czasie dyskretnym i jest podzielona na kroki. Różnicę czasu pomiędzy krokami oznacza się przez $\Delta t$. W każdym kroku iteracji, dla każdego elementu pracującego sprawdzany jest warunek zmiany stanu niezawodnościowego opisany równaniem:

gdzie:

$$
r n d \leq P_{Z},
$$

rnd - liczba losowa z przedziału $[0,1]$ o rozkładzie równomiernym,

$P_{Z}-$ prawdopodobieństwo zmiany stanu elementu $\mathrm{w}$ przedziale $(t, t+\Delta t)$ pod warunkiem, że element nie uszkodził się do chwili $t$.

Jeżeli warunek ten jest spełniony, następuje wtedy zmiana stanu eksploatacyjnego elementu $\mathrm{z}$ pracy na odnowę. Zmiana stanu $\mathrm{z}$ odnowy na rezerwę następuje zawsze po upływie określonego czasu naprawy. Zmiana stanu $\mathrm{z}$ rezerwy na odnowę wyznaczana jest $\mathrm{w}$ podobny sposób jak zmiana stanu z pracy na odnowę z tym, że czas dla elementu $w$ rezerwie płynie $p$ razy wolniej, gdzie $p$ jest parametrem wejściowym do symulacji.

Przedstawiony algorytm obliczeń zastosowano w symulacji układu o strukturze 2 z3 z elementami, których czasy pracy do uszkodzenia opisano rozkładem Weibulla wg poniższego wzoru $\mathrm{i}$ o parametrach przedstawionych $\mathrm{w}$ tabeli 1 . 
A concept of reliability assessment simulation model using systems structural...

Koncepcja modelu symulacyjnego do szacowania niezawodności z zastosowaniem..

W tabeli pokazano również pozostałe parametry wykorzystane w symulacji.

gdzie:

$$
f(t)=\frac{c}{s}\left(\frac{t}{s}\right)^{c-1} \exp \left(-\left(\frac{t}{s}\right)^{c}\right),
$$

$c$ - parametr kształtu,

$s$ - parametr skali.

Tab. 1 Parametry rozkładów Weibulla opisujacych niezawodność poszczególnych elementów $i$ czasy przeprowadzania odnów

\begin{tabular}{|c|c|c|c|c|}
\hline Element & $c$ & $s[\mathrm{dni}]$ & $t_{\text {odn }}[\mathrm{dni}]$ & $p$ \\
\hline 1 & 1,39 & 282,17 & 5 & 5 \\
\hline 2 & 1,39 & 1975,91 & 2 & 5 \\
\hline 3 & 1,39 & 1410,81 & 1 & 5 \\
\hline 4 & 1,39 & 846,49 & 4 & 5 \\
\hline
\end{tabular}

Niezawodność układu o strukturze 2 z3 uzyskana opracowaną metodą symulacyjną została pokazana na rysunku 4.

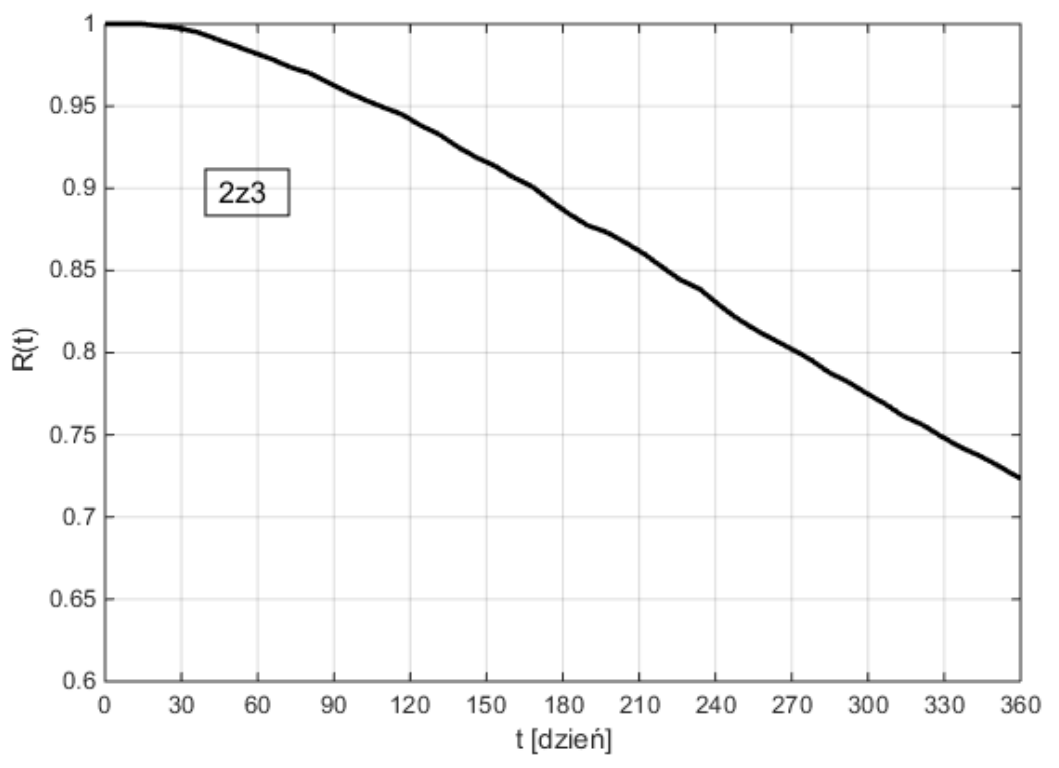

Rys. 4 Niezawodność uktadu o strukturze 2z3

otrzymana w wyniku eksperymentu symulacyjnego

Wyniki oszacowań niezawodności układu uzyskane za pomocą opracowanego modelu symulacyjnego pokazują, że niezawodność rozpatrywanego układu po okresie eksploatacji jednego roku osiąga wartość około 0,72. 
Jest to $\mathrm{w}$ głównej mierze uwarunkowane czasami przeprowadzania odnów poszczególnych elementów, które zależą od możliwości serwisu.

\section{Weryfikacja modelu symulacyjnego}

Dla potrzeb testowania zaproponowanego algorytmu symulacji niezawodności przeprowadzona została dekompozycja układu transportowego $\mathrm{w}$ dwóch poziomach. W wyniku dekompozycji wydzielono podukłady w postaci pojazdów realizujących zadania transportowe. Drugi poziom dekompozycji objął najważniejsze zespoły pojazdu takie jak: nadwozie, silnik, układ przeniesienia napędu i układ jezdny. Zespoły te stanowią elementy podukładów wydzielonych z całego analizowanego układu. W rozważanym przypadku analiza struktury funkcjonalnej oraz cechy konstrukcyjne i zadania eksploatacyjne obiektów (podukładów) powodują, że elementy występują w szeregowej strukturze niezawodnościowej. Struktura szeregowa ma niekorzystny wpływ na zachowanie się obiektu (podukładu) podczas eksploatacji i przyczynia się do znacznego spadku niezawodności w wyniku pogarszania niezawodności jednego z elementów. Mając na uwadze odwzorowanie rzeczywistej struktury niezawodnościowej obiektów zaproponowano strukturę typu kzn w postaci 2 z 3 pojazdów.

Weryfikację poprawności obliczeniowej opracowanego modelu symulacyjnego wykonano poprzez porównanie wyników uzyskanych z symulacji z wynikami otrzymanymi dla tego samego przypadku po zastosowaniu procesów Markowa. W tym celu rozpatrywano układ o strukturze $2 z 3$, w którym obiekty (podukłady) są jednorodne i każdy $\mathrm{z}$ nich składa się z 4 elementów tworzących strukturę szeregową. Czas pracy do uszkodzenia i trwania odnowy każdego $\mathrm{z}$ elementów opisywany jest rozkładem wykładniczym o parametrach przedstawionych w tabeli 2. Istotnym założeniem przyjętym $\mathrm{w}$ modelu jest fakt, że po uszkodzeniu dowolnego elementu cały podukład przechodzi do odnowy, w której odnawiany jest uszkodzony element $\mathrm{i}$ do chwili zakończenia jego odnowy pozostałe elementy tego podukładu nie ulegają uszkodzeniu.

Tab. 2 Intensywności uszkodzeń i odnowy elementów skladowych podukladu

\begin{tabular}{|c|c|c|c|}
\hline $\begin{array}{c}\mathrm{Nr} \\
\text { elementu }\end{array}$ & $\begin{array}{c}\text { Intensywność } \\
\text { uszkodzeń } \\
\lambda[1 / \text { dzień }]\end{array}$ & $\begin{array}{c}\text { Intensywność uszkodzeń } \\
\text { w rezerwie } \\
\lambda_{r}[1 / \text { dzień }]\end{array}$ & $\begin{array}{c}\text { Intensywność } \\
\text { odnowy } \\
\mu[1 / \text { dzień }]\end{array}$ \\
\hline 1 & $13,7 \cdot 10^{-3}$ & $2,74 \cdot 10^{-3}$ & 0,333 \\
\hline 2 & $0,548 \cdot 10^{-3}$ & $0,11 \cdot 10^{-3}$ & 0,25 \\
\hline 3 & $2,74 \cdot 10^{-3}$ & $0,548 \cdot 10^{-3}$ & 0,5 \\
\hline 4 & $16,4 \cdot 10^{-3}$ & $3,29 \cdot 10^{-3}$ & 0,2 \\
\hline
\end{tabular}


A concept of reliability assessment simulation model using systems structural...

Koncepcja modelu symulacyjnego do szacowania niezawodności z zastosowaniem. .

Graf procesu Markowa dla rozpatrywanego przypadku zamieszczono na rysunku 5.

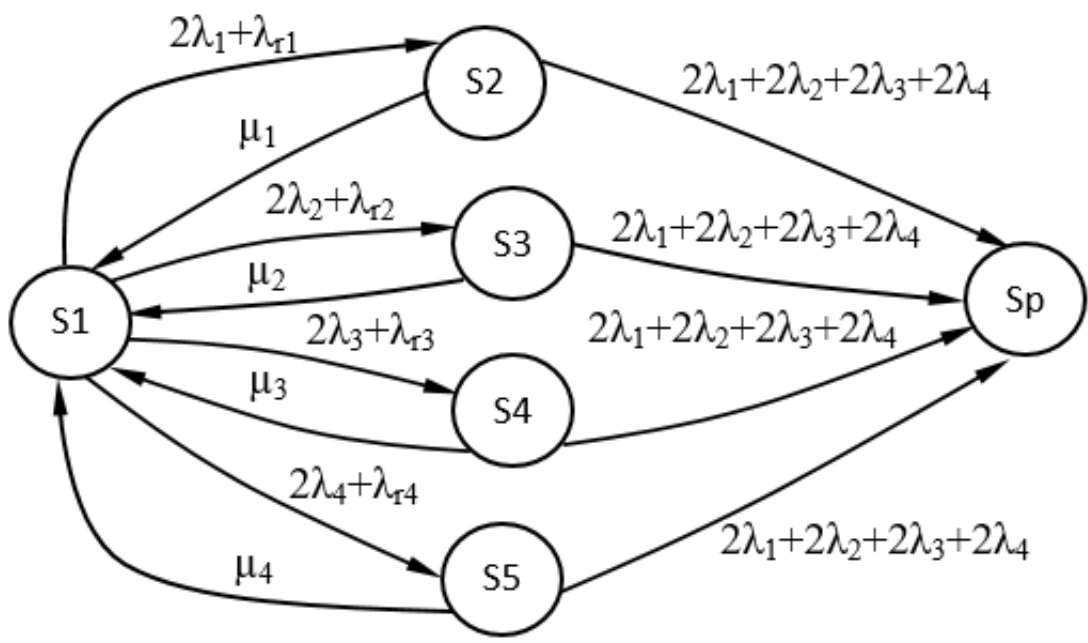

Rys. 5 Graf procesu Markowa dla uktadu $2 z 3$ wedtug proponowanego modelu obliczeniowego

Układ równań różniczkowych przyjmuje postać:

$$
\left\{\begin{aligned}
& \frac{\mathrm{d} P_{\mathrm{S} 1}(t)}{\mathrm{d} t}=-\left(2 \lambda_{1}+\lambda_{r 1}+2 \lambda_{2}+\lambda_{r 2}+2 \lambda_{3}+\lambda_{r 3}+2 \lambda_{4}+\lambda_{r 4}\right) P_{\mathrm{S} 1}(t)+ \\
&+\mu_{1} P_{\mathrm{S} 2}(t)+\mu_{2} P_{\mathrm{S} 3}(t)+\mu_{3} P_{\mathrm{S} 4}(t)+\mu_{4} P_{\mathrm{S} 5}(t) \\
& \frac{\mathrm{d} P_{\mathrm{S} 2}(t)}{\mathrm{d} t}=-\left(2 \lambda_{1}+2 \lambda_{2}+2 \lambda_{3}+2 \lambda_{4}+\mu_{1}\right) P_{\mathrm{S} 2}(t)+\left(2 \lambda_{1}+\lambda_{r 1}\right) P_{\mathrm{S} 1}(t) \\
& \frac{\mathrm{d} P_{\mathrm{S} 3}(t)}{\mathrm{d} t}=-\left(2 \lambda_{1}+2 \lambda_{2}+2 \lambda_{3}+2 \lambda_{4}+\mu_{2}\right) P_{\mathrm{S} 3}(t)+\left(2 \lambda_{2}+\lambda_{r 2}\right) P_{\mathrm{S} 1}(t) \\
& \frac{\mathrm{d} P_{\mathrm{S} 4}(t)}{\mathrm{d} t}=-\left(2 \lambda_{1}+2 \lambda_{2}+2 \lambda_{3}+2 \lambda_{4}+\mu_{3}\right) P_{\mathrm{S} 4}(t)+\left(2 \lambda_{3}+\lambda_{r 3}\right) P_{\mathrm{S} 1}(t) \\
& \frac{\mathrm{d} P_{\mathrm{S} 5}(t)}{\mathrm{d} t}=-\left(2 \lambda_{1}+2 \lambda_{2}+2 \lambda_{3}+2 \lambda_{4}+\mu_{4}\right) P_{\mathrm{S} 5}(t)+\left(2 \lambda_{4}+\lambda_{r 4}\right) P_{\mathrm{S} 1}(t)
\end{aligned}\right.
$$

Po wykonaniu obliczeń uzyskano wyniki w postaci zmian niezawodności układu w przyjętym horyzoncie obliczeń, co przedstawiono na rysunku 6 .

Na podstawie uzyskanych wyników można zauważyć, że występujące różnice $\mathrm{w}$ przebiegach niezawodności $\mathrm{z}$ modelu symulacyjnego i rozwiązania analitycznego są niewielkie. Można przyjąć, że symulacyjny model obliczeniowy funkcjonuje poprawnie i możliwe jest zastosowanie go do szacowania niezawodności układów tego typu w przypadku innych niż wykładnicze rozkładów prawdopodobieństwa czasów pracy do uszkodzenia i odnowy elementów. 


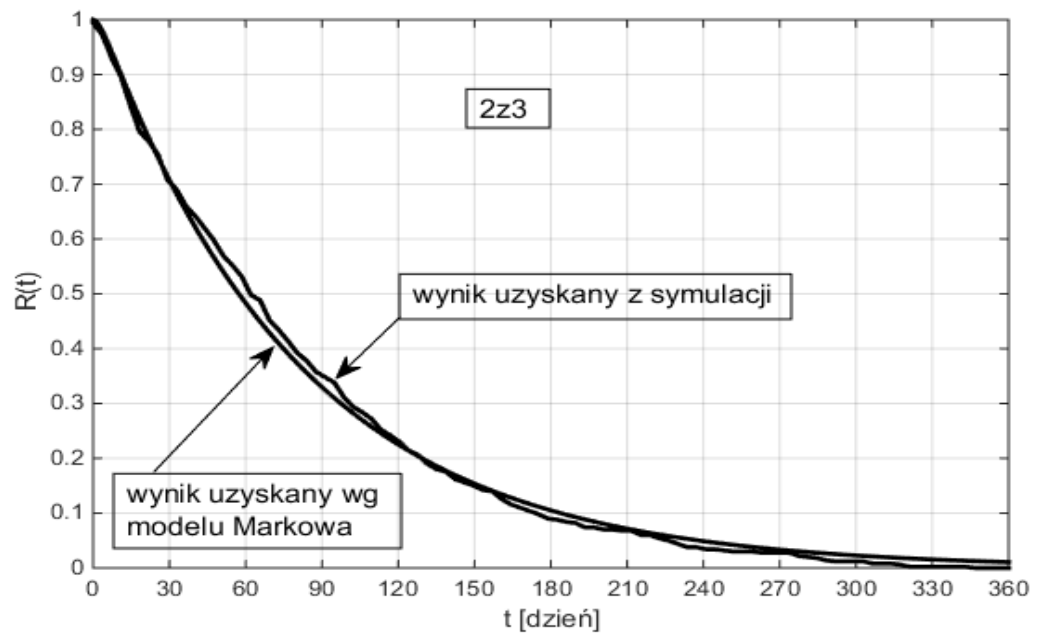

\section{Rys. 6 Niezawodność układu 2z3 uzyskana na drodze symulacji i z zastosowaniem procesów Markowa}

\section{Podsumowanie}

Przedstawiona w opracowaniu koncepcja modelu symulacyjnego i przeprowadzone obliczenia mają charakter oryginalny.

Koncepcja modelu polegała na strukturalnym podziale układu na trzy warstwy: układ, podukład i element. W odniesieniu do rzeczywistych układów transportowych podział ten można porównać odpowiednio do zbioru pojazdów (układu transportowego), pojazdów i ich podzespołów, od których zależeć będzie niezawodność całego układu. Niezawodność elementów opisywana była określonymi rozkładami prawdopodobieństwa o parametrach przyjętych na podstawie badań eksploatacyjnych. Podukłady składały się $\mathrm{z}$ elementów i funkcjonowały w strukturach progowych typu kzn. Wynikiem przeprowadzanych symulacji była ocena niezawodności całego układu.

Opracowany program symulacyjny został zweryfikowany w zakresie poprawności jego funkcjonowania. Weryfikacja dała pozytywne wyniki.

Istnieją możliwości rozbudowy opracowanego modelu o kolejną warstwę dekompozycji, w której elementem będzie część maszynowa wchodząca w skład podzespołu pojazdu będącego częścią układu transportowego.

\section{Literatura}

[1] Bradley E.: Reliability Engineering: A Life Cycle Approach. CRC Pres Taylor \& Francis Group. 2017.

[2] Faulin Fajardo J., Juan Perez A.A., Martorell Alsina S.S., Ramirez-Marquez J.E. (ed.): Simulation Methods for Reliability and Availability of Complex Systems. Springer. 2010. DOI 10.1007/978-1-84882-213-9.

[3] Fishman G.S.: Symulacja komputerowa. Pojęcia i metody. PWE. Warszawa. 1981. 
A concept of reliability assessment simulation model using systems structural...

Koncepcja modelu symulacyjnego do szacowania niezawodności z zastosowaniem. .

[4] Jaźwiński J., Pabis S., Wieremiejczyk W.: Zasady symulacji systemów technicznych, [w]: Symulacyjne metody badań niezawodności systemów technicznych 1. Materiały na „Szkołę Zimową - 75”. Sekcja Podstaw Eksploatacji Maszyn PAN. Ośrodek Postępu Technicznego. Katowice. 1975.

[5] Łatuszyńska M.: Metody symulacji komputerowej - próba klasyfikacji logicznej. Studies \& Proceedings of Polish Association for Knowledge Management. 2011; 41: 163-176.

[6] Młynarski S., Pilch R., Smolnik M., Szybka J., Wiązania G.: Formation of koon Systems Reliability Estimated with Analytical and Simulation Calculation Methods. Zapewnienie wymaganej niezawodności układów typu „kzn” szacowanej analitycznymi i symulacyjnymi metodami obliczeniowymi. Journal of KONBiN. 2017; 42: 255-272.

[7] Naylor T.H.: Modelowanie cyfrowe systemów ekonomicznych. PWN. Warszawa. 1975.

[8] Perkowski P.: Technika symulacji cyfrowej. WNT. Warszawa. 1980.

[9] Pidd M.: Computer Simulation in Management Science. John Wiley \& Sons. Chichester - New York- Weinheim - Brisbane- Singapore - Toronto. 1998.

[10] Pilch R., Smolnik M., Szybka J., Wiązania G.: Koncepcja strategii odnów profilaktycznych na przykładzie pojazdów szynowych komunikacji miejskiej [w] Siergiejczyk M. [red.]: Problemy utrzymania systemów technicznych. Oficyna Wydawnicza Politechniki Warszawskiej. Warszawa. 2014.

[11] Snopkowski R.: Symulacja stochastyczna. Uczelniane Wydawnictwa Naukowo-Dydaktyczne AGH. Kraków. 2007.

[12] Sowa A.: Ocena stanu technicznego pojazdów szynowych na podstawie cech zdeterminowanych. PK im. Tadeusza Kościuszki. Kraków. 2013.

[13] Tyszer J.: Symulacja cyfrowa. WNT. Warszawa. 1990.

Pracę wykonano w ramach Badań Statutowych prowadzonych w Akademii Górniczo-Hutniczej w Krakowie na Wydziale Inżynierii Mechanicznej i Robotyki, nr 11.11.130.174.

Stanistaw Mlynarski - pracownik naukowo-dydaktyczny Politechniki Krakowskiej (adiunkt). Specjalność $i$ zainteresowania naukowe $w$ dziedzinie eksploatacji, niezawodności oraz bezpieczeństwa maszyn, pojazdów i systemów technicznych (udziat 20\%).

Robert Pilch - pracownik naukowo-dydaktyczny (adiunkt), WIMiR, AGH. Zainteresowania naukowe: niezawodność i eksploatacja maszyn, bezpieczeństwo systemów technicznych, niezawodność układów sieciowych, odnawianie profilaktyczne obiektów technicznych (udziat 15\%).

Maksymilian Smolnik - pracownik naukowo-dydaktyczny (asystent) WIMiR, AGH. Zainteresowania naukowe: budowa i eksploatacja maszyn - zwłaszcza pojazdów, niezawodność środków technicznych, metodologia projektowania (udziat 20\%).

Jan Szybka (udziat 15\%)

Grzegorz Wiazania (udziat 30\%) 